\title{
Metazoan meiofaunal communities at cold seeps along the Norwegian margin: Influence of habitat heterogeneity and evidence for connection with shallow-water habitats
}

\author{
Saskia Van Gaever ${ }^{a},{ }^{*}$, Karine Olu $^{b}$, Sofie Derycke ${ }^{a}$ and Ann Vanreusel ${ }^{a}$ \\ a Marine Biology Section, Department of Biology, Ghent University, Krijgslaan 281/S8, 9000 Ghent, Belgium \\ b Département Environnement Profond, IFREMER, Centre de Brest, BP 70, 29280 Plouzané, France \\ *: Corresponding author : Van Gaever S., Tel.: +32 0926485 25; fax: +32 0926485 98, email \\ address : Saskia.VanGaever@UGent.be
}

\begin{abstract}
:
Cold-seep environments and their associated symbiont-bearing megafaunal communities create islands of primary production for macro- and meiofauna in the otherwise monotonous and nutrientpoor deep-sea environment. To examine the spatial variation and distribution patterns of metazoan meiobenthos in different seepage-related habitats, samples were collected in two regions off Norway: several pockmarks associated with the Storegga Slide including the Nyegga pockmark area $(730 \mathrm{~m}$; $64^{\circ} \mathrm{N}$ ), and the active, methane-venting Håkon Mosby Mud Volcano (HMMV) west of the Barents Sea $\left(1280 \mathrm{~m} ; 72^{\circ} \mathrm{N}\right)$. Based on sediment geochemistry and associated epifauna, three different habitat types were distinguished across the two regions: (1) reduced sediment with suboxic conditions, sometimes covered by bacterial mats, (2) sediment colonised by chemosynthetic, siboglinid tubeworms, and (3) sediment outside the influence of seepage and without a large chemosynthetic fauna. Meiofaunal communities varied strongly in terms of generic diversity and dominance among the different habitat types. Control sites and Siboglinidae polychaete fields both supported high nematode genus richness similar to normal deep-sea sediments, whereas the reduced sediments yielded a genus-poor nematode community dominated by one or two successful species. Meiofaunal densities in the different habitats were negatively correlated with macrobenthic densities. An extremely dense $\left(>11,000\right.$ ind $10 \mathrm{~cm}^{-2}$ ), mono-specific nematode population appeared to be restricted to the bacterial mats at HMMV. It consisted of a new cryptic species of the Halomonhystera disjuncta complex, which has been described from intertidal habitats in the North Sea. The reduced seep sediments at Nyegga did not yield $H$. disjuncta but were dominated by Terschellingia longicaudata, another cosmopolitan nematode species known to be abundant in organic-rich, oxygen-poor, shallow-water environments. These observations point to a past or recent connection between margins and shallow-water habitats.
\end{abstract}

Keywords: Cold seeps; Meiobenthos; Nematodes; Cryptic species; Halomonhystera disjuncta; Terschellingia longicaudata 


\section{Introduction}

In recent decades, the use of manned submersibles and Remotely Operated Vehicles (ROVs) has facilitated the observation and investigation of habitat heterogeneity at a large number of fluid escape zones on the deep-sea floor. In contrast to mid-oceanic ridge fluids, which are characterised by high temperature and high flow rates, fluids at margins tend to have lower temperatures and flow rates, and are therefore called cold seeps. In general, cold seeps are related to geological structures identified according to their seafloor expression: pockmarks, mud domes or mud volcanoes (Sibuet and Olu, 1998; Levin, 2005). Biological assemblages associated with cold seeps are typically dominated by large, symbiont-bearing megafauna (vesicomyid clams, mytilid mussels, siboglinid tubeworms) or by microbial mats that cover the sediment surface (Levin and Mendoza, 2007). These biochemically and biologically generated structures create distinct local 'habitats' for the infauna within seep sediments. The complexity of the biogenic structure, geochemical conditions and bacterial processes in the sediments are determining factors for the composition and diversity of macro- and meiofaunal communities. The macrofaunal communities associated with large biogenic structures such as mussel beds and tube-worm bushes seem to include numerous seep endemic species (e.g., Cordes et al., 2003; Turnipseed et al., 2003, 2004; Bergquist et al., 2003, 2005; Levin, 2005).

Previous investigations of metazoan seep meiofauna, covering a large variety of environments, water depths and geographic regions, revealed no consistent response to the seep conditions in terms of densities. Enhancement of meiofaunal abundances has been observed at shallow hydrocarbon seeps (16 m; Montagna et al., 1987), in eastern Pacific methane seeps in Monterey Bay (906 m; Buck and Barry, 1998), in microbial mats in the Gulf of Mexico (2230 m), on the Blake Ridge (2150 m; Robinson et al., 2004), on the Håkon Mosby Mud Volcano (HMMV) at $1280 \mathrm{~m}$ in the Barents Sea (Van Gaever et al., 2006) and on the mud volcano Atalante at $5000 \mathrm{~m}$ in the Barbados Trench (Olu et al., 1997). Little or no difference in densities compared to control sediments was reported for hydrocarbon seeps off Santa Barbara, California (15 m, Montagna and Spies, 1985), the Hatsuchima seep off Japan (1170 m; Shirayama and Ohta, 1990), brine seeps in the Gulf of Mexico (70 m; Powell and Bright, 1981; Powell et al. 1983) or methane seeps in the Black Sea (Sergeeva and Gulin, 2007). On the other hand, meiofaunal densities were significantly reduced at shallow methane seeps in the North Sea (150 m; Dando et al., 1991) and off Denmark (10 m; Jensen et al., 1992). In general, metazoan meiofaunal seep communities are composed largely of annelids and nematodes, with reduced species richness and elevated dominance compared to more typical deep-sea sediment environments. Densities are usually strongly influenced by the nematodes. However, at a shallow brine seep in the Gulf of Mexico $(72 \mathrm{~m}$; East Flower Garden), the meiofauna was dominated by gnathostomulids, with platyhelminths, nematodes and amphipods found in lower abundances (Powell and Bright, 1981; Powell et al., 1983). On the Blake Ridge, nematodes inhabiting Acrobacter microbial mats and mussel beds constituted similar proportions $(-30-50 \%)$ of the assemblage as the harpacticoid copepods (Robinson et al., 2004).

Nematode species that are reported to dominate seep sediments include Desmolaimoides thiobioticus (39\% of total community) in a brine seep in the Gulf of Mexico (Jensen, 1986), Astomonema southwardorum (31\% or 225 ind. $10 \mathrm{~cm}^{-2}$ ) in an active methane seep in the North Sea (Dando et al., 1991), Sabatieria punctata, Theristus anoxybioticus and Leptonemella aphanothecae in the methane seeps of the northern Kattegat (total meiofaunal densities: 650 ind. $10 \mathrm{~cm}^{-2}$; Jensen et al., 1992) and 2 Daptonema spp. (20.2 and 12.9\%) and a Chromadorita sp. (12.3\%) in a bathyal cold seep off Japan (Shirayama and Ohta, 1990). At the HMMV, unusually high densities (>11000 ind. $10 \mathrm{~cm}^{-2}$ ) of one dominant species, Halomonhystera disjuncta, were associated with bacterial mats (Van Gaever et al., 2006). This species, formerly described as Geomonhystera disjuncta (Bastian, 1865) (Monhysteridae), is a cosmopolitan marine species, reported from different shallow-water habitats including accumulations of detached kelp (mostly Laminaria saccharina) in Velikaya 
Salma Strait (15-18 m water depth, White Sea; Mokievsky et al., 2005), on macroalgal detritus along the coast of Belgium and the southwestern part of The Netherlands (Derycke et al., 2007), and in various marine sediments (Heip et al., 1985). A recent study showed that $H$. disjuncta from the southern North Sea actually consists of at least five cryptic species (Derycke et al., 2007) with subtle morphological differences (Fonseca et al., 2008).

To examine whether similar meiofaunal distribution patterns, and the dominance of a single nematode species seen at the HMMV, also characterise other seepage sites along the Norwegian margin, we sampled different habitats at the recently discovered pockmarks off mid-Norway. A new type of pockmark was observed along the northeastern flank of the Storegga Slide in the so-called Nyegga area during detailed seabed surveys with remote operated vehicles in 2003 and 2004. These pockmarks are morphologically more complex than the 'normal' seabed pockmarks found worldwide (Hovland and Judd, 1988), and occur as near-circular depressions, up to $15 \mathrm{~m}$ deep and $320 \mathrm{~m}$ wide. They contain ridges of methane-derived authigenic carbonate rock up to $10 \mathrm{~m}$ high and harbour pockmark-specific micro- and macrofauna, which include bacterial mats, fields of small tube-worms (Sclerolinum contortum and Oligobrachia haakonmosbiensis) and large pycnogonids (Hovland and Svensen, 2006).

In this study, we identified three distinct habitats (control sediment, reduced sediment, and Siboglinidae field) across both seepage regions (Håkon Mosby Mud Volcano at $72^{\circ} \mathrm{N} 14^{\circ} \mathrm{E}$; Storegga Slide/Nyegga at $64^{\circ} \mathrm{N} 05^{\circ} \mathrm{E}$ ). Control sediments were visually normal deep-sea sediments outside the influence of any seepage, while the Siboglinidae habitat was defined as sediments with dense aggregations (or fields) of chemosynthetic, siboglinid tubeworms. The third habitat, called 'reduced sediments', comprised sites with blackish, anoxic sediments, sometimes covered by bacterial mats. This last habitat includes the samples obtained at the black, reduced sediments at Nyegga or Storegga, which were sometimes colonised by white bacterial filaments, as well as the grey bacterial and white Beggiatoa mats at HMMV (Lichtschlag et al., 2006). To compare the data obtained from Storegga/Nyegga areas with those previously documented for HMMV, we added meiofaunal data from the control site, the Siboglinidae site and the Beggiatoa site at HMMV (Van Gaever et al., 2006) and two newly collected samples from the HMMV.

Based on this unique set of samples, we focussed on the following key questions. (1) To what extent do similar habitats at Nyegga and Storegga harbour meiofaunal communities comparable to those at the Håkon Mosby Mud Volcano? (2) Do infaunal macrofauna densities have any effect on the associated infaunal meiofauna communities? (3) What is the distribution range of the abundant HMMV nematode Halomonhystera disjuncta at other seepage sites along the Norwegian margin and what is the phylogenetic position of this morphospecies with respect to the $H$. disjuncta species complex (Derycke et al., 2007) from shallow-water habitats from the North Sea and The Netherlands?

\section{Material and methods}

\subsection{Study area}

We investigated the metazoan meiofauna from two regions along the Norwegian continental margin where evidence of fluid escapes was encountered. The first region was the active methane seeping Håkon Mosby Mud Volcano, situated west of the Barents Sea $\left(72^{\circ} \mathrm{N} 14^{\circ} \mathrm{E}\right)$ at an average water depth of $1280 \mathrm{~m}$ and at a distance of about $950 \mathrm{~km}$ north of the Storegga Slide (Fig. 1). This mud volcano was first observed in 1989 during a side scan sonar survey (Vogt et al., 1997). An expedition in 1995 recovered siboglinid tubeworms, indicating active chemosynthesis, measured very high temperature gradients in the sediments, and recovered methane hydrate from $2 \mathrm{~m}$ sub-bottom depth (Vogt et al., 1997). Apart from the Siboglinidae and Beggiatoa, the zoarcid fishes Lycodes spp. constituted the most abundant visible fauna at the HMMV (Gebruk et al., 2003). Initial identifications of other 
members of the HMMV benthic community (polychaetes, caprellid amphipods, pycnogonids, etc.) include common Norwegian-Greenland Sea species, which were also found in the nearby background samples, although at lower densities than those observed on the volcano (Gebruk et al., 2003).

The concentric structure of the mud volcano incorporates several sub-habitats with significantly different sediment geochemical characteristics (de Beer et al., 2006): (1) the flat central zone, corresponding to the area of mud flow expulsion from the inner crater, lacking epifauna or bacterial mats, (2) the extensive white mats of tangled Beggiatoa filaments (Pimenov et al., 2000) covering large areas around the centre, and smaller, grey mats located on the northern part of the volcano near the gas seep and containing a complex sulphur oxidising community (Beggiatoa of various thickness, Thiotrix and Thiomargarita; Niemann et al., 2006), (3) the dense methane- or sulphide-depending chemosynthetic macrofaunal communities surrounding the former habitats and dominated by Siboglinidae fields (Vogt et al., 1997; Gebruk et al., 2003). A predictive habitat map derived from video mosaic analysis confirmed this rather concentric distribution (Jerosh et al., 2007). The HMMV community lacks any large seep-specific symbiont-bearing mussels or clams (only small Thyasiridae bivalves mainly associated with Siboglinidae fields). Instead, it is dominated by two species of siboglinid tubeworms, Sclerolinum contortum and Oligobrachia haakonmosbiensis, both restricted to the crater zone and representing a remarkably high biomass (Pimenov et al., 2000; Gebruk et al., 2003). The HMMV has already been examined for meiofauna (Soltwedel et al., 2005; Van Gaever et al., 2006) and was revisited by the ROV Victor 6000 during the Vicking cruise aboard the RV "PourquoiPas?" in 2006.

The Storegga Slide (Bugge, 1983; Bünz et al., 2003) and the Nyegga area (Hovland et al., 2005; Hovland and Svensen, 2006), both located around $64^{\circ} \mathrm{N} 05^{\circ} \mathrm{E}$ off mid-Norway and characterised by the presence of a large complex of pockmarks, were sampled for the first time during the same cruise in order to describe the biological communities linked to coldseeps. The Storegga area is well known for its giant Holocene slide, one of the largest ever mapped on a continental margin (Fig. 1) (Paull et al., 2008). On the northeastern flank of this feature, complex pockmarks are located in the Nyegga area at $740 \mathrm{~m}$ water depth. The deepest and most spectacular pockmark, called 'G11', was sampled in this study. It measures about $220 \mathrm{~m}$ in diameter and is approximately $12 \mathrm{~m}$ deeper than the surrounding general seafloor. Stalked crinoids up to $30 \mathrm{~cm}$ tall, abundant large ophiuroids (basket stars, up to $1 \mathrm{~m}$ diameter), together with hydrozoans and numerous other unidentified sessile organisms, were perched at specific sites on the large carbonate rocks of the ridges (Hovland et al., 2005). Hovland et al. (2005) and Hovland and Svensen (2006) inferred that these pockmarks harbour a chemosynthetic micro-organic community, fuelled by advecting hydrocarbon-associated fluids. If so, they would resemble the HMMV environment, even though there is no visual seepage at the Nyegga complex pockmarks. It is believed that the Nyegga pockmarks were formed by a single sudden ('catastrophic') fluid flow and that subsequent small-scale seepage is still active (Hovland et al., 2005).

\subsection{Sampling strategy and habitats}

Meiofaunal and macrofaunal sediment samples were collected at the Storegga Slide, the Nyegga area and the Håkon Mosby Mud Volcano during the Vicking cruise aboard the RV "PourquoiPas?" in May-June 2006 (Fig. 1, Table 1). Samples for both meio- and macrofauna were retrieved at a Siboglinidae field and nearby visibly 'normal' deep-sea floor on the wider Storegga Slide and in the Nyegga area. Additional meiofaunal samples were collected in blackish sediments at Nyegga, and in grey bacterial mats at the HMMV, both regarded as reduced sediments. Additional macrofaunal samples were collected at the HMMV in a Siboglinidae patch and in areas covered with Beggiatoa mats. In each case, two or more replicate cores for meiofauna and/or macrofauna were taken (Table 1). Meiofaunal samples at control sites were sampled with a multiple corer (one deployment per control site, tube surface of $30.2 \mathrm{~cm}^{2}$ ), while the other sites were sampled with push cores operated by the 
ROV Victor 6000 (surface of $21.2 \mathrm{~cm}^{2}$ ). Macrofaunal samples were collected as sub-samples from a USNEL boxcorer or blade cores operated by the ROV. Macrofaunal samples were stored as bulk samples and sieved over a $0.5 \mathrm{~mm}$ mesh sieve. All organisms were sorted out and counted. Detailed study of macrofaunal community structure will be published separately (C. Decker, personal communication).

One meiofaunal sample (PL277-07 CT9) taken at the grey bacterial mat site at HMMV was used as a bulk sample, fixed in acetone and stored for later molecular analyses. The other meiofaunal samples were fixed in $4 \%$ buffered formaldehyde and washed over a $32 \mu \mathrm{m}$ mesh sieve. Metazoan meiofauna were extracted by density gradient centrifugation, using Ludox (a colloidal silica polymer; specific gravity 1.18) as a flotation medium (Heip et al., 1985). All material was fixed with $4 \%$ buffered formalin and stained with Rose Bengal. The metazoan meiofauna was sorted out, enumerated and identified down to major taxa under the stereomicroscope. From each sample, 100 nematodes were picked out randomly, mounted onto glycerine slides using the formalin-ethanol-glycerol technique of Seinhorst (1959), and identified to genus level according to Warwick et al. (1998).

\subsection{Molecular analysis}

The Beggiatoa and grey mats at the Håkon Mosby Mud Volcano were dominated by one morphospecies, identified as Halomonhystera disjuncta. To confirm this morphology-based identification, we extracted DNA (following the procedure of Derycke et al., 2005) from 13 specimens from the HMMV grey mats that had been preserved in acetone. Only 2 out of the 13 specimens yielded a PCR product for the $18 \mathrm{~S}$ gene. To increase DNA yield, we pooled together 3 and 9 specimens, respectively, in two tubes. After DNA preparation, ca. 790 bp of the ribosomal $18 \mathrm{~S}$ gene were amplified with primers G18S4 (5'-GCT TGT CTC AAA GAT TAA GCC-3') and 4R (5'- GTA TCT GAT CGC CKT CGA WC-3'). In addition, 307 bp of the ribosomal D2D3 region of the $28 \mathrm{~S}$ gene were amplified with primers D2/F1 (5'TTCGACCCGTCT TGAAACACG-3') and D3b (5'- TCC TCG GAA GGA ACC AGC TAC TA$\left.3^{\prime}\right)$, and the internal transcribed spacer region (ITS) was amplified with primers Vrain 2F (5'CTT TGT ACA CAC CGC CCG TCG CT-3') and Vrain 2R (5'-TTT CAC TCG CCG TTA CTA AGG GAA TC-3'). For ITS, we were unable to retrieve any PCR product. In addition to the nuclear fragments, we amplified $422 \mathrm{bp}$ of the mitochondrial COI gene with the primers JB2 (5'-ATGTTTTGATTTTACCWGCWTTYGGTGT-3') and JB5GED (5'AGCACCTAAACTTAAAACATARTGRAARTG-3') from Derycke et al. (2007). PCR conditions were as in Derycke et al. (2005), except for the annealing temperature, which was $50^{\circ} \mathrm{C}$ for $\mathrm{COI}, 54^{\circ} \mathrm{C}$ for $\mathrm{D} 2 \mathrm{D} 3$ and $52^{\circ} \mathrm{C}$ for $18 \mathrm{~S}$. The extension time was 30 s for $\mathrm{COI}, 45 \mathrm{~s}$ for D2D3 and 90 s for $18 \mathrm{~S}$. For $\mathrm{COI}$ and D2D3, 35 cycles were run, while 40 cycles were used to amplify the $18 \mathrm{~S}$ fragment. Sequencing was performed as described in Derycke et al. (2008a) and all sequences deposited in Genbank under accession numbers FM164283 (18S), FM164282 (D2D3) and FM164281 (COI). All sequences were aligned in ClustalX v 1.81 (Thompson et al., 1997) using default alignment parameters (gap opening/gap extension costs for 15/6.66). To ensure that our specimens belong to Halomonhystera disjuncta, a maximum parsimony analysis was performed with Paup 4.0 beta 10 (Swofford, 1998) using the $18 \mathrm{~S}$ sequences from a broad range of genera across the phylum, including all marine genera from Meldal et al. (2007). In addition, we compared the D2D3 and COI sequences with published sequences from the Halomonhystera disjuncta species complex (Derycke et al., 2007) and with sequences from four other closely related monhysterid nematode species from shallow waters: Diplolaimelloides meyli (AM748756), D. oschei (AM748757), D. deleyi (AM748758) and Diplolaimella dievengatensis (AM748759). A neighbour-joining tree based on p-distances was constructed using MEGA v3.1 (Kumar et al., 2004). 


\subsection{Statistical analysis}

Non-metric multidimensional scaling (MDS) ordination using the Bray-Curtis similarity measure was applied to visualize the (dis)similarity between habitats from Nyegga, Storegga and HMMV with respect to the nematode genus composition. The stress value gives a measure for goodness-of-fit for the MDS ordination: a low stress value $(<0.2)$ indicates a good ordination with no real prospect of a misleading interpretation (Clarke, 1993). One-way Analysis of similarities (ANOSIM) was carried out to test for significant differences in the community structure between different habitats or regions. Similarity of Percentages (SIMPER) was used to investigate the degree of (dis)similarity between habitats in terms of nematode genus composition. All analyses mentioned above were performed with the PRIMER5 software (Plymouth Marine Laboratory; Clarke and Gorley, 2001). The STATISTICA6 software was used to calculate the product-moment correlation between meiofaunal and macrofaunal densities.

\section{Results}

\subsection{Metazoan meiofaunal communities associated with similar habitats at the Håkon Mosby Mud Volcano, Storegga Slide and Nyegga area}

The most abundant meiofaunal taxon in all samples was the Nematoda, accounting for 86$98 \%$ of the total metazoan meiofauna (Fig. 2, Table 2), while adult copepods and their naupliar larvae always constituted the second most abundant group. Meiofaunal sized polychaetes were present at every site. Amphipods, bivalves, kinorhynchs, loriciferans, ostracods, tanaids, tardigrades and turbellarians exhibited lower relative abundances and were not found at all sites. Total meiofaunal densities were highly variable between the different sites, and also within the same habitat type (Fig. 2). For instance, the Siboglinidae habitat harboured maximum meiofaunal densities in the Nyegga area (mean \pm SD: $7028 \pm$ 1279 ind. $\left.10 \mathrm{~cm}^{-2}\right)$ and minimum densities at the Storegga Slide $\left(41 \pm 22\right.$ ind. $\left.10 \mathrm{~cm}^{-2}\right)$. Meiofaunal densities at the control sites also varied strongly, with values at Nyegga (1878 \pm 524 ind. $\left.10 \mathrm{~cm}^{-2}\right)$ and Storegga $\left(3643 \pm 473\right.$ ind. $\left.10 \mathrm{~cm}^{-2}\right)$ being 2 to 4 times as high as those from the HMMV $\left(968 \pm 156\right.$ ind. $\left.10 \mathrm{~cm}^{-2}\right)$.

The (dis)similarities in meiofaunal communities among all sites are illustrated in an ordination plot based on the relative abundance of the nematode genera. The reduced sediments are clearly separated from the Siboglinidae habitat (SIMPER dissimilarity 93.9\%) and the control sediments (SIMPER dissimilarity 95.6\%) (Fig. 3). The nematode communities observed in the reduced sediments habitat were characterised by a low diversity in terms of genera number (19 \pm 6 genera), and the very high dominance of only one or two nematode species (Table 3). The white and grey bacterial mat sites from the Håkon Mosby Mud Volcano were grouped together in the MDS plot (Fig. 3), reflecting the high relative abundance of Halomonhystera disjuncta in the samples and its absence in all other habitats. The reduced sediments at Nyegga plotted separately from the bacterial mat sites (Fig. 3) because of their totally different nematode community composition (SIMPER dissimilarity $=97.6 \%$ ), made up of two equally dominant species: Thalassomonhystera sp. (40\%) and Terschellingia longicaudata (36\%) (Table 3).

The control sediments were inhabited by a typical, genus-rich (66 \pm 6 genera) deep-sea nematode assemblage, with high relative abundances of Acantholaimus (Chromadoridae), Thalassomonhystera (Monhysteridae), Tricoma (Desmoscolecidae) and Leptolaimus (Leptolaimidae) (Table 3). The Siboglinidae fields at the HMMV and Nyegga area harboured a similar genus-rich (64 \pm 9 genera) nematode assemblage, but with a different suite of dominant genera compared to the control sediments: Aponema (Microlaimidae), Terschellingia (Linhomoeidae), Sabatieria (Comesomatidae) and Metalinhomoeus (Linhomoeidae) (Table 3). A distinct nematode community, comprising an unusually low number of nematode genera (20), extremely low nematode densities $\left(39 \pm 21\right.$ ind. $\left.10 \mathrm{~cm}^{-2}\right)$, 
and the highest relative abundances of Sabatieria (41.0\%) and Rhabdocoma (15.4\%), characterised the Storegga Siboglinidae habitat. Consequently, the two samples from this site plotted some distance from the other Siboglinidae and control samples (Fig. 3). An ANOSIM analysis indicated a significant effect $(R=0.606 ; p=0.003)$ of the habitat type on the nematode community composition within the cluster of the remaining Siboglinidae and control samples.

\subsection{Comparison between macro- and meiofaunal densities}

Average total macrofaunal densities in the control sediments $\left(5081 \pm 39\right.$ ind. $\mathrm{m}^{-2}$ ) were of the same order of magnitude as the average densities found in the Siboglinidae fields (6778 \pm 747 ind. $\mathrm{m}^{-2}$ ) in the Nyegga area and the Håkon Mosby Mud Volcano. In contrast, average macrofaunal densities at the Storegga Siboglinidae site $\left(12083 \pm 7582\right.$ ind. $\left.\mathrm{m}^{-2}\right)$ were twice as high as those at Nyegga and the HMMV. Polychaetes, dominated by the families Lumbrineridae and Dorvilleidae, (M. Morineaux, pers. comm.), made up $67 \%$ of the assemblage. The sediments underneath Beggiatoa mats at the HMMV yielded very low average macrofaunal densities (1463 \pm 1544 ind $\mathrm{m}^{-2}$ ), consisting almost entirely of polychaetes in the family Capitellidae (M. Morineaux, pers. comm.). When mean meiofaunal densities at the different sites were plotted against the corresponding mean macrofaunal densities (Fig. 4), a negative linear correlation $(R=-0.79)$ was detected, although there were some very high standard deviations for the macrofauna.

\subsection{Molecular characterisation and presence of the nematode Halomonhystera disjuncta along the Norwegian margin}

Extremely high densities $\left(11069 \pm 2269\right.$ ind. $\left.10 \mathrm{~cm}^{-2}\right)$ of the monhysterid Halomonhystera disjuncta accounted for $98 \%$ of the total nematode community in the Beggiatoa mats at the HMMV (Van Gaever et al., 2006). This species was also dominant (95\%) in samples from the grey bacterial mats at the HMMV, although it occurred in much lower densities $(1075 \pm 757$ ind. $10 \mathrm{~cm}^{-2}$ ). The species was not represented in the other HMMV habitats outside the bacterial mats site (except for a very few individuals in the methane rich centre of the mud volcano), and not a single individual was found in the samples from the different habitats at Storegga and Nyegga.

Molecular analyses were performed on $\mathrm{H}$. disjuncta specimens collected at the HMMV grey bacterial mats to confirm the morphological identification at the species level. The $18 \mathrm{~S}$ sequences obtained from 2 specimens were identical to each other and clustered within the Monhysteridae clade shown in Meldal et al. (2007), where they were most similar to the Halomonhystera disjuncta (formerly known as Geomonhystera disjuncta) sequence. The $18 \mathrm{~S}$ sequences were $2.3 \%$ different from those of the $H$. disjuncta complex from offshore Belgium and The Netherlands (data not shown). Similarly, the D2D3 sequences were 1-6.1\% different from those of five cryptic $H$. disjuncta species (Derycke et al., 2007). The phylogenetic tree of the COI sequences confirmed that the HMMV nematodes were more closely related to the $H$. disjuncta sequences than to the other monhysterid species (Fig. 5). Divergence levels of COI between the HMMV sequence and the $H$. disjuncta sequences (20.4-27.0\%) were of the same magnitude as those observed between the cryptic $H$. disjuncta species. In view of these results using three molecular markers (18S, D2D3, COI), the specimens from the HMMV grey mats most likely represent another cryptic species within the $H$. disjuncta species complex. 


\section{Discussion}

\subsection{Metazoan meiofaunal communities associated with similar habitats at the Håkon Mosby Mud Volcano, Storegga Slide and Nyegga area}

In general, meiobenthic densities at the control sites on the Storegga Slide and in the Nyegga area (1878-3643 ind. $10 \mathrm{~cm}^{-2}$ ) were clearly enhanced compared to typical densities at similar water depths in the Eastern Atlantic (about 1000 ind. $10 \mathrm{~cm}^{-2}$; Soltwedel, 2000). The high meiofaunal densities in the background sediments can be attributed to increased primary production and subsequent enhanced sedimentation of particulate organic matter at the time of sampling (23 May-6 June), although further investigations are needed to confirm this link. Seasonal fluctuations in primary production were measured in the Norwegian Sea, with a spring bloom driven by the light regime and starting already in mid April (Irigoien et al., 1998).

Habitat heterogeneity generated by biogenic structures is also known to influence the distribution and abundance of species in marine environments (Bergquist et al., 2003). Organisms increase habitat heterogeneity by various processes, with the provision of physical structures representing the most widespread and important process. Here, we examined the structuring effect of different habitat types on meiobenthic communities in two fluid escape areas along the Norwegian margin. Habitat type has proven to be a significant factor determining the generic composition of nematode assemblages. For the Norwegian seeps, our results indicate a principal distinction between the nematode communities in seep sediments colonised by siboglinids and communities in reduced, anoxic seep sediments lacking symbiont-bearing megafauna. From the different seep sites investigated, it became clear that Siboglinidae tubeworm fields harbour the most diverse nematofauna. It has been suggested that the siboglinids strongly affect the geochemical conditions in the sediment surrounding their tubes as a result of their intensive ventilation activity (Julian et al., 1999; Bergquist et al., 2002). This creates a well-oxygenated sediment up to $5 \mathrm{~cm}$ depth (de Beer et al., 2006), providing a suitable habitat for a wide range of nematode species. Siboglinidae fields and control sediments both yielded highly diverse nematode assemblages, but a shift in dominant families and genera was detected. In contrast, reduced sediments always supported a unique and species-poor nematode community, dominated by one or two nematode genera belonging to the families Monhysteridae and Linhomoeidae.

The reduced sediments at the HMMV, covered by white or grey bacterial mats, were inhabited by Halomonhystera disjuncta in highly variable densities. The blackish, anoxic sediments in the Nyegga area, which lacked bacterial mats, exhibited a completely different nematode community with high relative abundances of the species Terschellingia longicaudata (Linhomoeidae). Like $H$. disjunct, this nematode is a common inhabitant of intertidal habitats with an extensive geographical range including estuarine sediments in the North Sea (Heip et al., 1985; Vranken et al., 1988; 1989), the mangrove mudflats off northeastern Australia (Alongi, 1987; Nicholas et al., 1991; Fisher and Sheaves, 2003) and the southeast coast of India (Chinnadurai and Fernando, 2007), off the Atlantic coast of France, in the Black Sea (Sergeeva, 1991) and the Gulf of Mexico, off eastern China (Qingdao province) (Zhang and Ji, 1994) as well as New Zealand and the Solomon Islands (Burgess et al., 2005). Another example of a cosmopolitan nematode species colonising reduced cold seep sediments is Sabatieria mortenseni. This species was observed in a cold seep adjacent to the Congo canyon in the Gulf of Guinea (South Atlantic) (Van Gaever et al., accepted), but previously had been reported from littoral sediments off Brazil, the USA, Antarctica and in the Strait of Magellan (Chile) (Van Gaever et al., accepted).

We conclude that seep sediments strongly affected by reduced fluids generate a habitat that is difficult to exploit by most of the typical deep-sea nematode species. In our study, only cryptic species belonging to a species complex with a wide geographical range were able to colonise these anoxic, sulphidic environments. Seaweed (Fucus sp.), which was observed at 
the HMMV, may function as a possible transport medium for nematode species if the exchange took place from the shallow- to the deep-water habitats. There are also examples of macrofaunal taxa (although not at the species level) that support this hypothesis, particularly at the shallowest seeps. The eastern Mediterranean cold-seep fauna is dominated by several bivalves belonging to families (Lucinidae) and genera (the Modiolinae Idas) usually found in organic-rich mud in coastal waters or organic remains such as sunken wood (Olu-Le Roy et al., 2004). Nevertheless, the structure of the nematode community associated with an isolated reduced habitat within a cold deep-sea seep will certainly depend on several factors, for instance the presence of food resources (bacteria), tolerance levels to environmental stress, and dispersal capacities.

\subsection{Relationship with macrofaunal densities}

We observed a negative correlation between the macrobenthic densities and the corresponding meiobenthic densities. A clear example was found in the Siboglinidae patch at Storegga, where the very abundant macrobenthos $\left(12083 \pm 7582\right.$ ind. $\left.\mathrm{m}^{-2}\right)$, strongly driven by a dense polychaete assemblage, was accompanied by extremely low meiofaunal densities $\left(41 \pm 22\right.$ ind. $\left.10 \mathrm{~cm}^{-2}\right)$. Several studies have indicated the importance of infaunal polychaetes as structuring agents of meiofaunal assemblages, either by predation or by sediment disturbance (e.g., Ronn et al, 1988; Tita et al., 2000). The sediment reworking activity of polychaetes can also have a positive effect on the meiobenthos due to the deeper aeration of the sediments and the creation of oxic micro-environments (De Troch et al., 2000). In the Storegga tubeworm fields, however, the unusually high-density polychaete populations (>12000 ind. $\mathrm{m}^{-2}$ compared to 3444 ind. $\mathrm{m}^{-2}$ in Nyegga tubeworm fields) were strongly dominated by two carnivorous families, the Lumbrineridae and Dorvilleidae. Obviously, the dense population of these non-siboglinid polychaetes inhabiting the Siboglinidae patch at Storegga will cause intensive predation pressure and a strong negative effect on the infaunal nematode assemblage.

In contrast, the lowest macrofaunal densities in the HMMV Beggiatoa mats were associated with the maximum meiofaunal densities found in this study. Probably, the harsh, almost lethal, geochemical sediment conditions have a severe impact on the colonisation success of macrofaunal species, resulting in a less abundant macrobenthos and a lower predation pressure and disturbance effect on the thriving Halomonhystera disjuncta population.

\subsection{Molecular characterisation and presence of the nematode Halomonhystera disjuncta along the Norwegian margin}

Species of the Monhysteridae, a common deep-sea nematode family, seem to be generalists that inhabit extreme environments such as vents and seeps (Van Gaever et al., 2006; Zekely et al., 2006; Copley et al., 2007; Gollner et al., 2007). At the Håkon Mosby Mud Volcano, a remarkably dense population of the monhysterid Halomonhystera disjuncta was associated with the bacterial mat habitat, where total nematode densities significantly exceeded those found at the control sites (Van Gaever et al., 2006). This species was absent outside the bacterial mats, except for very low numbers in the central part of the mud volcano, indicating a strong preference for the Beggiatoa dominated mats. Halomonhystera disjuncta was also completely absent in the different habitats sampled in seepage sites at Storegga and Nyegga, including the reduced sediments.

Apart from a few meiofaunal polychaetes, no other metazoan meio- or macrofaunal species were present in these anoxic, sulphidic sediments at the Beggiatoa mats. Ecotoxicological experiments with $\mathrm{H}$. disjuncta from intertidal habitats provided evidence of a high resistance to environmental stress, especially to heavy metals (Vranken et al., 1989). The individuals obtained from the HMMV showed no obvious morphological modifications compared to the shallow-water species. Even the ovoviviparous reproduction mode of the HMMV species was also observed in the shallow-water populations, although this characteristic was facultative 
and usually expressed in toxic environments (A. Boffé, unpublished data). The internal development of juveniles most likely secures the survival and growth of the vulnerable brood within the permanently sulphidic and anoxic sediments (Van Gaever et al., 2006). In addition, analyses of the fatty acids and stable isotopic signatures of $H$. disjuncta (Van Gaever et al., submitted) indicated that this species proliferates on chemosynthetically derived carbon, in particular on the highly abundant sulphide-oxidising bacteria, and is therefore trophically adapted to conditions within the HMMV bacterial mats.

Halomonhystera disjuncta is a strong coloniser in shallow waters, successfully exploiting different substrata such as marine sediments as well as decomposing algal thalli. Moreover, observations of other species rafting on seaweed (Derycke et al., 2007) suggest that nematodes have substantial dispersal capacities, despite lacking pelagic larvae. It is likely that $H$. disjuncta also occurs in shallow water along the shallow Norwegian coasts, since this species has been reported from the North Sea south of Norway (Vranken et al., 1988) and the White Sea northeast of Norway (Mokievsky et al., 2005). The HMMV, which is more distant from land, may have been colonised by individuals of $H$. disjuncta floating on seaweeds originating from nearby intertidal habitats. Similarly, Van Dover et al. (2002) hypothesised that some seep invertebrate species may be derived from shallow-water species. However, our observations do not exclude the possibility of migration via stepping stones from the deep sea to shallow water. Further molecular investigations of the nematode communities at nearby intertidal and deep-sea habitats are required to resolve these issues.

The fact that this cryptic $H$. disjuncta species is able to flourish in such high densities at the HMMV bacterial mats could have two possible explanations, which are not mutually exclusive. Derycke et al. (2007) suggested that $H$. disjuncta may exhibit priority effects, i.e. the first colonising individuals have such a strong population development that they inhibit the settlement of new species. The second explanation is that the geochemical conditions within these sediment, i.e. high sulphide levels and oxygen depletion beneath $2 \mathrm{~mm}$ sediment depth (de Beer et al., 2006; Van Gaever et al., 2006), create a lethal environment for almost all metazoan life. The nematode $H$. disjuncta, previously shown to thrive in sulphidic, shallow marine sediments (Heip et al., 1985), may be pre-adapted to these toxic conditions and therefore able to colonise and exploit this extreme deep-sea habitat.

The molecular analyses of Halomonhystera specimens from the HMMV bacterial mats confirmed its identification as Halomonhystera disjuncta. When the $18 \mathrm{~S}$ sequence was compared to $18 \mathrm{~S}$ sequences from a broad range of marine nematode taxa, it was most similar to that of this species. A comprehensive genetic study carried out on $\mathrm{H}$. disjuncta specimens collected in estuaries and coastal zones of Belgium and the southwestern part of The Netherlands revealed high levels of molecular diversity within this species. Five distinct, co-occurring lineages in the mitochondrial $\mathrm{COI}$ gene were found on a small spatial scale, showing low divergence levels within lineages $(<3 \%)$ and high divergence levels between lineages (> 13\%) (Derycke et al., 2007). The specimens from the HMMV most likely represent another cryptic species of the $H$. disjuncta species complex, as the patterns in the two sets of independently evolving gene fragments (nuclear versus mitochondrial) were concordant and the divergence levels were comparable with those found between known nematode species (Derycke et al., 2007). Several recent studies have shown that some meiobenthic morpho species are indeed complexes of cryptic species, each with a much more restricted geographical distribution than the putatively cosmopolitan species (Schmidt and Westheide, 2000; Rocha-Olivares et al., 2001; Bhadury et al., 2008; Derycke et al., 2008b).

\section{Conclusions}

In the rather homogeneous and oligotrophic deep-sea environment, seeps can be considered as nutrient-rich islands with patchily distributed sub-habitats, each harbouring its specific epi- and infauna. Seep sediments, which are strongly affected by reduced fluids and recognised by typical geochemical features (e.g., oxygen depletion, toxic sulphide levels, exclusion of most metazoan life, often high bacterial biomass), represent a unique niche for 
some very stress-resistant nematode species. Molecular analyses of Halomonhystera specimens from the reduced HMMV sediments provided evidence that these nematodes may belong to an intertidal species complex. The reduced sediments at Nyegga are dominated by another cosmopolitan shallow nematode species, Terschellingia longicaudata, known from anoxic, marsh and mangrove mudflats. These observations point to an exchange of nematode species between shallow-water habitats and deep-sea seeps. The siboglinid tubeworm habitats found at the different seeps along the Norwegian margin generally host a similar high number of meiobenthic nematode genera. However, total densities of macrofauna were negatively correlated with infaunal meiobenthic densities, in particular with nematode densities. Especially at sites colonised by extremely dense populations of non-siboglinid polychaetes, nematode communities were significantly impoverished in terms of abundance and generic diversity. In conclusion, the seepageaffected regions with multiple habitat types scattered along the Norwegian margin support several significantly different meiobenthic communities, and therefore contribute to the diversification and persistence of the resident deep-sea meiofauna.

\section{Acknowledgements}

The authors would like to thank IFREMER (France) for a successful collaboration and for providing sampling facilities on board the 'PourquoiPas?'. We thank the Captain, the ship crew, the ROV crew, and the head scientist Hervé Nouzé for their efforts during the sampling campaign Vicking in 2006, and all other scientists onboard who assisted during sampling. We are also indebted to Annelien Rigaux for the molecular analyses of the nematodes. Special thanks go to Andy Gooday and three anonymous reviewers for critically reading the manuscript and for providing many constructive remarks. This research was supported the GOA fund from Ghent University, the $6^{\text {th }}$ FP HERMES, the FWO project 'Cold Seeps' nr. G034607, and the BOF project nr. 01J13207, and MarBEF (Network of Excellence). This publication is contribution number MPS-08050 of MarBEF (Marine Biodiversity and Ecosystem Functioning).

\section{References}

Alongi, D.M., 1987. Inter-estuary variation and intertidal zonation of free-living nematode communities in tropical mangrove systems. Marine Ecology Progress Series 40, 103-114.

Bergquist, D.C., Urcuyo, I.A., Fisher, C.R., 2002. Establishment and persistence of seep vestimentiferan aggregations from the upper Louisiana slope of the Gulf of Mexico. Marine Ecology Progress Series 241, 89-98.

Bergquist, D.C., Ward, T., Cordes, E.E., McNelis, T., Howlett, S., Koisoff, R., Hourdez, S., Carney, R., Fisher, C.R., 2003. Community structure of vestimentiferan-generated habitat islands from Gulf of Mexico cold seeps. Journal of Experimental Marine Biology and Ecology 289, 197-222.

Bergquist, D.C., Fleckenstein, C., Knisel, J., Begley, B., MacDonald, I.R., Fisher, C.R., 2005. Variations in seep mussel bed communities along physical and chemical environmental gradients. Marine Ecology Progress Series 293, 99-108.

Bhadury, P., Austen, M.C., Bilton, D.T., Lambshead, P.J.D., Rogers, A.D., Smerdon, G.R., 2008. Evalution of combined morphological and molecular techniques for marine nematode (Terschellingia spp.) identification. Marine Biology 154, 509-518.

Buck, K.R., Barry, J.P., 1998. Monterey bay cold seep infauna: quantitative comparison of bacterial mat meiofauna with non-seep control sites. Cahiers de Biologie Marine 39, 333335. 
Bugge, T., 1983. Submarine slides on the Norwegian continental margin, with special emphasis on the Storegga area. Continental Shelf Institute Publication, ISSN 0332-5288, vol. 110. $152 \mathrm{pp}$.

Bünz, S., Mienert, J., Berndt, C., 2003. Geological controls on the Storegga gas-hydrate system of the mid-Norwegian continental margin. Earth and Planetary Science Letters 209, 292-307.

Burgess, R., Sharma, J., Carr, R.S., Montagna, P., 2005. Assessment of storm water outfalls in Corpus Christi Bay, Texas, USA using meiofauna. Meiofauna Marina 14, 157-169.

Chinnadurai, G., Fernando, O.J., 2007. Meiofauna of mangroves of the southeast coast of India with special reference to the free-living marine nematode assemblage. Estuarine, Coastal and Shelf Science 72, 329-336.

Clarke, K.R., 1993. Non-parametric multivariate analyses of changes in community structure. Australian Journal of Ecology 18, 117-143.

Clarke, K.R., Gorley, R.N., 2001. PRIMER v5: User Manual/Tutorial. PRIMER-E, Plymouth.

Copley, J.T.P., Flint, H.C., Ferrero, T.J., Van Dover, C.L., 2007. Diversity of meiofauna and free-living nematodes in hydrothermal vent mussel beds on the northern and southern East Pacific Rise. Journal of the Marine Biological Association of the UK 87, 1141-1152.

Cordes, E.E., Bergquist, D.C., Shea, K., Fisher, C., 2003. Hydrogen sulphide demand on long-lived vestimentiferan tube worm aggregations modifies the chemical environment at hydrocarbon seeps. Ecology Letters 6, 212-219.

Dando, P.R., Austen, M.C., Burke, R.A., Kendall, M.A., Kennicutt II, M.C., Judd, A.C., Moore, D.C., O'Hara, S.C.M., Schmaljohann, R., Southward, A.J., 1991. Ecology of a North Sea pockmark with an active methane seep. Marine Ecology Progress Series 70, 49-63.

de Beer, D., Sauter, E., Niemann, H., Kaul, N., Foucher, J.P., Witte, U., Schlüter, M., Boetius, A., 2006. In situ fluxes and zonation of microbial activity in surface sediments of the Håkon Mosby Mud Volcano. Limnology and Oceanography 51, 1315-1331.

Derycke, S., Remerie, T., Vierstraete, A., Backeljau, T., Vanfleteren, J., Vincx, M., Moens, T., 2005. Mitochondrial DNA variation and cryptic speciation within the free-living marine nematode Pellioditis marina. Marine Ecology Progress Series 300, 91-103.

Derycke, S., Backeljau, T., Vlaeminck, C., Vierstraete, A., Vanfleteren, J., Vincx, M., Moens, T., 2007. Spatiotemporal analysis of population genetic structure in Geomonhystera disjuncta (Nematoda, Monhysteridae) reveals high levels of molecular diversity. Marine Biology 151, 1799-1812.

Derycke, S., Fonseca, G., Vierstraete, A., Vanfleteren, J., Vincx, M., Moens, T., 2008a. Disentangling taxonomy within the Rhabditis (Pellioditis) marine (Nematoda, Rhabditidae) species complex using molecular and morphological tools. Zoological Journal of the Linnean Society 152, 1-15.

Derycke, S., Remerie, T., Backeljau, T., Vierstraete, A., Vanfleteren, J., Vincx, M., Moens, T., 2008b. Phylogeography of the Rhabditis (Pellioditis) marine species complex: evidence for long-distance dispersal, and for range expansions and restricted gene flow in the NE Atlantic. Molecular Ecology 17, 3306-3322.

De Troch, M., Fiers, F., Vincx, M., 2000. Range extension and microhabitat of Lightiella incise (Cephalocarida). Journal of Zoology 251, 199-204.

Fisher, R., Sheaves, M.J., 2003. Community structure and spatial variability of marine nematodes in tropical Australian pioneer seagrass meadows. Hydrobiologia 495, 143-158.

Fonseca, G., Derycke, S., Moens, T., 2008. Integrative taxonomy in two free-living nematode species complexes. Biological Journal of the Linnean Society 94, 737-753.

Gebruk, A.V., Krylova, E.M., Lein, A.Y., Vinogradov, G.M., Anderson, E., Pimenov, N.V., Cherkashev, G.A., Crane, K., 2003. Methane seep community of the Håkon Mosby mud volcano (the Norwegian Sea): composition and trophic aspects. Sarsia 88, 394-403.

Gollner, S., Zekely, J., Govenar, B., Le Bris, N., Nemeschkal, H.L., Fisher, C.R., Bright, M., 2007. Tubeworm-associated permanent meiobenthic communities from two chemically different hydrothermal vent sites on the East Pacific Rise. Marine Ecology Progress Series 337, 39-49. 
Heip, C., Vincx, M., Vranken, G., 1985. The ecology of marine nematodes. Oceanography and Marine Biology - an Annual Review 23, 399-489.

Hovland, M., Judd, A.G., 1988. Seabed Pockmarks and Seepages. Graham and Trotman, London, 293 pp.

Hovland, M., Svensen, H., Forsberg, C.F., Johansen, H., Fichler, C., Fosså, J.H., Jonsson, F., Rueslåtten, H., 2005. Complex pockmarks with carbonate-ridges off mid-Norway: products of sediment degassing. Marine Geology 218, 191-206.

Hovland, M., Svensen, H., 2006. Submarine pingoes: indicators of shallow gas hydrates in a pockmark at Nyegga, Norwegian Sea. Marine Geology 228, 15-23.

Irigoien, X., Head, R., Klenke, U., Meyer-Harms, B., Harbour, D., Niehoff, B., Hirche, H.-J., Harris, R., 1998. A high frequency time series at Weathership M, Norwegian Sea, during the 1997 spring bloom: feeding of adult female Calanus finmarchicus. Marine Ecology Progress Series 172, 127-137.

Jensen, P., 1986. Nematode fauna in the sulphide-rich brine seep and adjacent bottoms of the East Flower Garden, NW Gulf of Mexico. Marine Biology 92, 489-503.

Jensen, P., Aagaard, I., Burke, R.A., Dando, P., Jorgensen, N., Kuijpers, A., Laier, T., O'Hara, S., Schmaljohann, R., 1992. 'Bubbling reefs' on the Kattegat: submarine landscapes of carbonate-cemented rocks support a diverse ecosystem at methane seeps. Marine Ecology Progress Series 83, 103-112.

Jerosch, K., Schlüter, M., Foucher, J.-P., Allais, A.G., Klages, M., Edy, C., 2007. Spatial distribution of mud flows, chemoautotrophic communities, and biogeochemical habitats at Håkon Mosby Mud Volcano. Marine Geology 243: 1-17.

Julian, D., Gaill, F., Wood, E., Arp, A.J., Fisher, C.R., 1999. Roots as a site of hydrogen sulphide uptake in the hydrocarbon seep vestimentiferan Lamellibrachia sp. Journal of Experimental Biology 202, 2245-2257.

Kumar, S., Tamura, K., Nei, M., 2004. MEGA3: integrated software for molecular evolutionary genetics analysis and sequence alignment. Briefings in Bioinformatics 5, 150163.

Levin, L.A., 2005. Ecology of cold seep sediments: interactions of fauna with flow, chemistry and microbes. Oceanography and Marine Biology: an Annual Review 43, 1-46.

Levin, L.A., Mendoza, G.F., 2007. Community structure and nutrition of deep methane-seep macrobenthos from the North Pacific (Aleutian) Margin and the Gulf of Mexico (Florida Escarpment). Marine Ecology 28, 131-151.

Lichtschlag, A., Roey, H., Niemann, H., Boetius, A., Klages, M., de Beer, D., 2006. Microbial turnover of sulfide in combination with iron precipitation at the Håkon Mosby Mud Volcano. Geophysical Research Abstracts 8, 07069.

Meldal, B.H.M., Debenham, N.J., De Ley, P., De Ley, I.T., Vanfleteren, J.R., Vierstraete, A.R., Bert, W., Borgonie, G., Moens, T., Tyler, P.A., Austen, M.C., Blaxter, M.L., Rogers, A.D., Lambshead, P.J.D., 2007. An improved molecular phylogeny of the Nematoda with special emphasis on marine taxa. Molecular Phylogenetics and Evolution 42, 622-636.

Mokievsky, V.O., Filippova, K.A., Chesunov, A.V., 2005. Nematode fauna associated with detached kelp accumulations in the subtidal zone of the White Sea. Oceanology 45, 689697.

Montagna, P.A., Spies, R.B., 1985. Meiofauna and chlorophyll associated with Beggiatoa mats of a natural submarine petroleum seep. Marine Environmental Research 16, 231-242.

Montagna, P.A., Bauer, J.E., Toal, J., Hardin, D., Spies, R.B., 1987. Temporal variability and the relationship between benthic meiofaunal and microbial populations of a natural coastal petroleum seep. Journal of Marine Research 45, 761-789.

Nicholas, W.L., Elek, J.A., Stewart, A.C., Marples, T.G., 1991. The nematode fauna of a temperate Australian mangrove mudflat; its population density, diversity and distribution. Hydrobiologia 209, 13-27.

Niemann, H., Lösekann, T., de Beer, D., Elvert, M., Nadalig, T., Knittel, K., Amann, R., Souter, E.J., Schlüter, M., Klages, M., Foucher, J.-P., Boetius, A., 2006. Novel microbial communities of the Haakon Mosby mud volcano and their role as a methane sink. Nature 443, 854-858. 
Olu, K., Lance, S., Sibuet, M., Hendry, P., Fiala-Dedioni, A., Dinet, A., 1997. Cold seep communities as indicators of fluid expulsion patterns through mud volcanoes seaward of the Barbados Accretionary Prism. Deep-Sea Research Part I 44, 811841.

Olu-Le Roy, K., Sibuet, M., Fiala-Mendioni, A., Gofas, S., Salas, C., Mariotti, A., Foucher, J.P., Woodside, J., 2004. Cold seep communities in the deep eastern Mediterranean Sea: composition, symbiosis and spatial distribution on mud volcanoes. Deep-Sea Research Part I 51, 1915-1936.

Paull, C.K., Ussler III, W., Holbrook, W.S., Hill, T.M., Keaten, R., Mienert, J., Haflidason, H., Johnson, J.E., Winters, W.J., Lorenson, T.D., 2008. Origin of pockmarks and chimney structure on flanks of the Storegga Slide, offshore Norway. Geo-Marine Letters 28: 43-51.

Pimenov, N.V., Savvichev, A.S., Rusanov, I.I., Lein, A.Y., Ivanov, M.V., 2000. Microbiological processes of the carbon and sulfur cycles at cold methane seeps of the North Atlantic. Microbiology 69,709-720.

Powell, E.N., Bright, T.J., 1981. A thiobios does exist - Gnathostomulid domination of the canyon community at the East Flower Garden brine seep. Internationale Revue der gesamten Hydrobiologie 66, 675-683.

Powell, E.N., Bright, T.J., Woods, A., Gittings, S., 1983. Meiofauna and the thiobios in the East Flower Garden Brine Seep. Marine Biology 73, 269-283.

Robinson, C.A., Bernhard, J.M., Levin, L.A., Mendoza, G.F., Blanks, J.K., 2004. Surficial hydrocarbon seep infauna from the Blake Ridge (Atlantic Ocean, $2150 \mathrm{~m}$ ) and the Gulf of Mexico (690-2240m). PSZN: Marine Ecology 25, 313-336.

Rocha-Olivares, A., Fleeger, J.W., Foltz, D.W., 2001. Decoupling of molecular and morphological evolution in deep lineages of a meiobenthic harpacticoid copepod. Molecular Biology and Evolution 18: 1088-1102.

Ronn, C., Bonsdorff, E., Nelson, W., 1988. Predation as a mechanism of interference within infauna in shallow brackish water soft bottoms, experiments with an infaunal predator Nereis diversicolor O.F. Müller. Journal of Experimental Marine Biology and Ecology 116, 143-157.

Schmidt, H., Westheide, W., 2000. Are the meiofaunal polychaetes Hesionides arenaria and Stygocapitella subterranean true cosmopolitan species? Results of RAPD-PCR investigations. Zoologica Scripta 29, 17-27.

Seinhorst, J.W., 1959. A rapid method for the transfer of nematodes from fixative to unhydrous glycerine. Nematologica 4, 67-69.

Sergeeva, N.G., 1991. Unusual polyamphidity of natural population on Terschellingia longicaudata de Man, 1907 (Nematoda, Monhysterida, Linhomoeidae) in the Black Sea. Ecol morjais 39, 70-73.

Sergeeva, N.G., Gulin, M.B., 2007. Meiobenthos from an active methane seepage area in the NW Black Sea. Marine Ecology 28, 152-159.

Shirayama, Y., Ohta, S., 1990. Meiofauna in a cold-seep community off Hatsushima, Central Japan. Journal of the Oceanographical Society of Japan 46, 118-124.

Sibuet, M., Olu, K., 1998. Biogeography, biodiversity and fluid dependence of deep-sea coldseep communities at active and passive margins. Deep-Sea Research Part II 45, 517-567.

Soltwedel, T., 2000. Metazoan meiobenthos along continental margins: a review. Progress in Oceanography 46, 59-84.

Soltwedel, T., Portnova, D., Kolar, I., Mokievsky, V., Schewe, I., 2005. The small-sized benthic biota of the Håkon Mosby Mud Volcano (SW Barents Sea slope). Journal of Marine Systems 55, 271-290.

Swofford, D.L., 1998. PAUP*. Phylogenetic Analysis Using Parsimony (*and other methods). Version 4. Sinauer Associates, Sunderland.

Thompson, J.D., Gibson, T.J., Plewniak, F., Jeanmougin, F., Higgins, D.G., 1997. The Clustal_X windows interface: flexible strategies for multiple sequence alignment aided by quality analysis tools. Nucleic Acids Research 24, 4876-4882. 
Tita, G., Desrosiers, G., Vincx, M., Nozais, C., 2000. Predation and sediment disturbance effects of the intertidal polychaete Nereis virens (Sars) on associated meiofaunal assemblages. Journal of Experimental Marine Biology and Ecology 243, 261-282.

Turnipseed, M., Knick, K.E., Lipcius, R.N., Dreyer, J., Van Dover, C.L., 2003. Diversity in mussel beds at deep-sea hydrothermal vents and cold seeps. Ecology Letters 6, 518-523.

Turnipseed, M., Jenkins, C.D., Van Dover, C.L., 2004. Community structure in Florida Escarpment seep and Snake Pit (Mid-Atlantic Ridge) vent mussel beds. Marine Biology 145, 121-132.

Van Dover, C.L., German, C.R., Speer, K.G., Parson, L.M., Vrijenhoek, R.C., 2002. Evolution and biogeography of deep-sea vent and seep invertebrates. Science 295, 1253-1257.

Van Gaever, S., Moodley, L., de Beer, D., Vanreusel, A., 2006. Meiobenthos at the Arctic Håkon Mosby Mud Volcano, with a parental-caring nematode thriving in sulphide-rich sediments. Marine Ecology Progress Series 321, 143-155.

Van Gaever, S., Galéron, J., Sibuet, M., Vanreusel, A., accepted. Deep-sea habitat heterogeneity influence on meiofaunal communities in the Gulf of Guinea. Deep-Sea Research II.

Van Gaever, S., Moodley, L., Pasotti, F., Houtekamer, M., Middelburg, J.J., Danovaro, R., Vanreusel, A., submitted. Trophic specialisation of metazoan meiofauna at the Håkon Mosby Mud Volcano: fatty acid biomarker isotope evidence. Marine Biology.

Vogt, P.R., Cherkashev, A., Ginsburg, G.D., Ivanov, G.I., Crane, K., Lein, A.Y., Sundvor, E., Pimenov, N.V., Egorov, A.V., 1997. Haakon Mosby mud volcano: a warm methane seep with seafloor hydrates and chemosynthesis-based ecosystem in late Quantemary Slide Valley, Bear Island Fan, Barents Sea passive margin. EOS Transactions of the American Geophysical Union Supplement 78 (17), 187-189.

Vranken, G., Herman, P.M.J., Heip, C., 1988. Studies of the life-history and energetics of marine and brackish-water nematodes. I. Demogaphy of Monhystera disjuncta at different temperature and feeding conditions. Oecologia 77, 296-301.

Vranken, G., Tiré, C. Heip, C., 1989. Effect of temperature and food on hexavalent chromium toxicity to the marine nematode Monhystera disjuncta. Marine Environmental Research 27, 127-136.

Warwick, R.M., Platt, H.M., Somerfield, P.J., 1998. Free-living Marine Nematodes Part III Monhysterids. In: Barnes, R.S.K., Crothers, J.H. (Eds.), Synopses of the British Fauna (New Series). The Linnean Society of London, Shrewsbury, pp. 1-296.

Zekely, J., Sørensen, V.M., Bright, M., 2006. Three new nematode species (Monhysteridae) from deep-sea hydrothermal vents. Meiofauna Marine 15, 25-42.

Zhang, Z., Ji, R., 1994. The first record of Terschellingia longicaudata De Man 1907 in prawn pond. Journal Ocean University Qingdao 24, 214-221.

\section{Tables}


Table 1

Sampling locations, water depth $(\mathrm{m})$, latitudes and longitudes of sampling sites, sampling device, dive and core numbers, fraction of fauna sampled, and number of replicates. * denotes data published in Van Gaever et al. (2006)

\begin{tabular}{|c|c|c|c|c|c|c|c|c|}
\hline Sampling location & $\begin{array}{l}\text { water depth } \\
(\mathrm{m})\end{array}$ & latitude $\left({ }^{\circ} \mathrm{N}\right)$ & longitude $\left({ }^{\circ} \mathrm{E}\right)$ & sampling device & dive number & core number & fauna & $\begin{array}{l}\text { no. of } \\
\text { replicates }\end{array}$ \\
\hline \multicolumn{9}{|l|}{ Nyegga } \\
\hline Control site & 720 & $64^{\circ} 40.16^{\prime}$ & $05^{\circ} 17.38^{\prime}$ & boxcorer & & $\mathrm{BC} 3$ & macro & 4 \\
\hline Control site & 719 & $64^{\circ} 40.17^{\prime}$ & $05^{\circ} 17.39^{\prime}$ & multicorer & & MT3 & meio & 2 \\
\hline Siboglinidae patch & 732 & $64^{\circ} 39.99^{\prime}$ & $05^{\circ} 17.35^{\prime}$ & blade corer & PL272-02 & $\mathrm{CL} 7+8$ & macro & 2 \\
\hline $\begin{array}{l}\text { Siboglinidae patch on G11 } \\
\text { depression }\end{array}$ & 733 & $64^{\circ} 40.00^{\prime}$ & $05^{\circ} 17.34^{\prime}$ & push corer & PL272-02 & CT14+18 & meio & 2 \\
\hline $\begin{array}{l}\text { Reduced sediment (black } \\
\text { spot) }\end{array}$ & 733 & $64^{\circ} 39.79^{\prime}$ & $05^{\circ} 17.29^{\prime}$ & push corer & PL272-02 & $\mathrm{CT} 1+8$ & meio & 2 \\
\hline \multicolumn{9}{|l|}{ Storegga Nord Est } \\
\hline Control site & 742 & $64^{\circ} 45.28^{\prime}$ & $05^{\circ} 06.22$ & boxcorer & & $\mathrm{BC} 1$ & macro & 3 \\
\hline Control site & 720 & $64^{\circ} 45.28^{\prime}$ & $05^{\circ} 06.21^{\prime}$ & multicorer & & MT2 & meio & 2 \\
\hline Siboglinidae patch & 745 & $64^{\circ} 45.27^{\prime}$ & $04^{\circ} 58.87^{\prime}$ & blade corer & PL275-05 & $\mathrm{CL} 5+7$ & macro & 2 \\
\hline Siboglinidae patch & 746 & $64^{\circ} 45.27^{\prime}$ & $04^{\circ} 58.87^{\prime}$ & push corer & PL275-05 & CT5+6 & meio & 2 \\
\hline \multicolumn{9}{|l|}{ Håkon Mosby Mud Volcano } \\
\hline - Control site * & 1296 & $71^{\circ} 58.97^{\prime}$ & $14^{\circ} 45.41^{\prime}$ & multicorer & & PS 64/395 & meio & 1 \\
\hline Control site * & 1885 & $71^{\circ} 41.96^{\prime}$ & $13^{\circ} 26.10^{\prime}$ & multicorer & & PS $64 / 390$ & meio & 2 \\
\hline Siboglinidae patch & 1261 & $72^{\circ} 00.34^{\prime}$ & $14^{\circ} 42.76^{\prime}$ & blade corer & PL277-07 & $\mathrm{CL} 7+8$ & macro & 2 \\
\hline Siboglinidae patch * & 1288 & $72^{\circ} 00.05^{\prime}$ & $14^{\circ} 44.14^{\prime}$ & multicorer & & PS 64/356-357-367 & meio & 3 \\
\hline Beggiatoa mats & 1258 & $72^{\circ} 00.17^{\prime}$ & $14^{\circ} 43.94^{\prime}$ & blade corer & PL276-06 & CL6+7+8 & macro & 3 \\
\hline Beggiatoa mats * & 1287 & $72^{\circ} 00.18^{\prime}$ & $14^{\circ} 43.81^{\prime}$ & multicorer & & PS 64/321-323-324 & meio & 3 \\
\hline grey bacterial mats & 1255 & $72^{\circ} 00.32^{\prime}$ & $14^{\circ} 43.38^{\prime}$ & push corer & PL277-07 & $\mathrm{CT} 2+5+9$ & meio & 2 \\
\hline
\end{tabular}


Table 2

Densities of all metazoan meiofaunal taxa and relative abundances of Nematoda, Harpacticoida and nauplii $(0$ to $10 \mathrm{~cm}$ ) for the different sites. SD = standard deviation

\begin{tabular}{|c|c|c|c|c|c|c|}
\hline \multirow[b]{2}{*}{ Subhabitat } & \multicolumn{3}{|c|}{ Nyegga } & \multicolumn{2}{|c|}{ Storegga } & \multirow{2}{*}{$\begin{array}{l}\text { HMMV } \\
\text { grey mats } \\
\text { mean (SD) }\end{array}$} \\
\hline & $\begin{array}{l}\text { reduced } \\
\text { sed } \\
\text { mean (SD) }\end{array}$ & $\begin{array}{l}\text { Siboglinidae } \\
\text { mean (SD) }\end{array}$ & $\begin{array}{l}\text { control } \\
\text { mean (SD) }\end{array}$ & $\begin{array}{l}\text { Siboglinidae } \\
\text { mean (SD) }\end{array}$ & $\begin{array}{l}\text { control } \\
\text { mean (SD) }\end{array}$ & \\
\hline \multicolumn{7}{|l|}{$\begin{array}{l}\text { Density } \\
\text { (ind. } / 10 \mathrm{~cm}^{2} \text { ) }\end{array}$} \\
\hline Acari & & $0,2(0,3)$ & & & & \\
\hline Amphipoda & & $3,5(1,7)$ & & & $0,7(0,0)$ & \\
\hline Bivalvia & $0,2(0,3)$ & $12,5(3,0)$ & $1,8(1,2)$ & & $2,2(0,7)$ & \\
\hline Gastropoda & & & & & $0,2(0,2)$ & \\
\hline Gastrotricha & & $0,5(0,7)$ & & & & \\
\hline Harpacticoida & $8,5(5,3)$ & $211,2(105,5)$ & $32,3(5,4)$ & $0,9(1,3)$ & $39,7(6,1)$ & $45,4(35,0)$ \\
\hline Hydrozoa & & & $0,7(0,9)$ & & & \\
\hline Isopoda & & & & & $0,2(0,2)$ & \\
\hline Kinorhyncha & & $0,9(1,3)$ & $0,2(0,2)$ & & $0,2(0,2)$ & \\
\hline Loricifera & & $0,5(0,7)$ & $0,8(1,2)$ & & $0,5(0,2)$ & \\
\hline Nauplii & $30,4(29,0)$ & $169,7(56,3)$ & $27,8(3,7)$ & $0,2(0,3)$ & $41,1(14,5)$ & $14,1(9,3)$ \\
\hline Nematoda & $287,7(26,6)$ & $6590,6(1098,9)$ & $1784,3(511,6)$ & $39,1(20,6)$ & $3536,1(454,7)$ & $1137,0(693,8)$ \\
\hline Ophiuroidea & & $0,2(0,3)$ & & & & \\
\hline Ostracoda & & $11,1(11,7)$ & $5,6(1,4)$ & & $4,6(0,5)$ & $0,7(1,0)$ \\
\hline Polychaeta & $5,2(6,0)$ & $20,2(6,0)$ & $13,7(0,7)$ & $0,5(0,7)$ & $14,2(2,8)$ & $0,2(0,3)$ \\
\hline Sipuncula & & & $0,3(0,5)$ & & & \\
\hline Tanaidacea & $0,9(1,3)$ & $7,3(6,3)$ & & & $0,5(0,7)$ & \\
\hline Tardigrada & & & $9,9(2,3)$ & & $2,6(0,9)$ & \\
\hline Turbellaria & & & $0,7(0,9)$ & & & $0,7(1,0)$ \\
\hline Total & $333(69)$ & 7028 (1279) & $1878(524)$ & $41(22)$ & $3643(473)$ & $1198(717)$ \\
\hline $\begin{array}{l}\text { Relative } \\
\text { abundance (\%) }\end{array}$ & & & & & & \\
\hline $\begin{array}{l}\text { Copepoda }+ \\
\text { nauplii }\end{array}$ & $11,7 \%$ & $5,4 \%$ & $3,2 \%$ & $2,9 \%$ & $2,2 \%$ & $5,0 \%$ \\
\hline Nematoda & $86,4 \%$ & $93,8 \%$ & $95,0 \%$ & $96 \%$ & $97,1 \%$ & $94,9 \%$ \\
\hline
\end{tabular}


Table 3

Relative abundances of the ten most important nematode genera at the different sites.

\begin{tabular}{|c|c|c|c|c|c|c|c|c|c|}
\hline \multicolumn{2}{|l|}{$\begin{array}{l}\text { Nyegga } \\
\text { Reduced sed }\end{array}$} & \multicolumn{2}{|l|}{ Siboglinidae } & \multicolumn{2}{|l|}{ Control } & \multicolumn{2}{|l|}{$\begin{array}{l}\text { Storegga } \\
\text { Siboglinidae }\end{array}$} & \multicolumn{2}{|l|}{ Control } \\
\hline Genus & $\%$ & Genus & $\%$ & Genus & $\%$ & Genus & $\%$ & Genus & $\%$ \\
\hline Monhystera & 40.1 & Aponema & 17.1 & Acantholaimus & 12.6 & Sabatieria & 39.7 & Leptolaimus & 21.5 \\
\hline Terschellingia & 35.9 & Terschellingia & 11.8 & Thalassomonhystera & 12 & Rhabdocoma & 13.1 & Richtersia & 8.4 \\
\hline Aponema & 7.2 & Sabatieria & 8.5 & Tricoma & 10.3 & Leptolaimus & 7.3 & Acantholaimus & 8.1 \\
\hline Spilophorella & 3.2 & Tricoma & 7.9 & Greeffiella & 7.3 & Rhabdodemania & 7.2 & Thalassomonhystera & 6.6 \\
\hline Prochromadora & 2.5 & Metalinhomoeus & 6.1 & Halalaimus & 6.8 & Neochromadora & 6,0 & Tricoma & 5.8 \\
\hline Sabatieria & 2.3 & Halalaimus & 5.9 & Leptolaimus & 6.3 & Paramonhystera & 6,0 & Metalinhomoeus & 5.2 \\
\hline Thalassomonhystera & 1.9 & Acantholaimus & 4.1 & Amphimonhystrella & 4.8 & Thalassomonhystera & 3.7 & Rhabdodemania & 4.2 \\
\hline Syringolaimus & 1 & Amphimonhystera & 3.6 & Microlaimus & 3.3 & Syringolaimus & 2.5 & Halalaimus & 3.8 \\
\hline Halalaimus & 0.9 & Desmoscolex & 3.4 & Sabatieria & 3 & Monhystera & 2.4 & Desmoscolex & 3.4 \\
\hline Linhomoeus & 0.9 & Thalassomonhystera & 3 & Metadesmolaimus & 2.7 & Halalaimus & 2.1 & Microlaimus & 3.4 \\
\hline
\end{tabular}

\begin{tabular}{|c|c|c|c|c|c|c|c|}
\hline $\begin{array}{l}\text { HMMV } \\
\text { Beggiatoa mats }\end{array}$ & & Grey mats & & Siboglinidae & & Control & \\
\hline Genus & $\%$ & Genus & $\%$ & Genus & $\%$ & Genus & $\%$ \\
\hline Halomonhystera & 99.6 & Halomonhystera & 91.2 & Monhystera & 12.7 & Acantholaimus & 14.3 \\
\hline Sabatieria & 0.2 & Prochromadora & 3.5 & Microlaimus & 8.9 & Monhystera & 13.4 \\
\hline Laimella & $<0.1$ & Sabatieria & 2.1 & Acantholaimus & 7.4 & Halalaimus & 7.3 \\
\hline Tricoma & $<0.1$ & Thalassomonhystera & 1.3 & Comesa & 7.1 & Tricoma & 7.2 \\
\hline Neochromadora & $<0.1$ & Draconematidae & 1.1 & Daptonema & 6.6 & Linhystera & 4.9 \\
\hline Theristus & $<0.1$ & Syringolaimus & 0.6 & Halalaimus & 6.1 & Desmoscolex & 3.9 \\
\hline Linhystera & $<0.1$ & Desmoscolex & 0.1 & Amphimonhystrella & 5.9 & Neochromadora & 3.6 \\
\hline Monhystera & $<0.1$ & Tricoma & 0.1 & Theristus & 5.1 & Monhystrella & 3.5 \\
\hline Daptonema & $<0.1$ & Manganonema & $<0.1$ & Sabatieria & 4 & Leptolaimus & 2.5 \\
\hline Viscosia & $<0.1$ & Halalaimus & $<0.1$ & Tricoma & 3.1 & Sabatieria & 2.4 \\
\hline
\end{tabular}




\section{Figures}

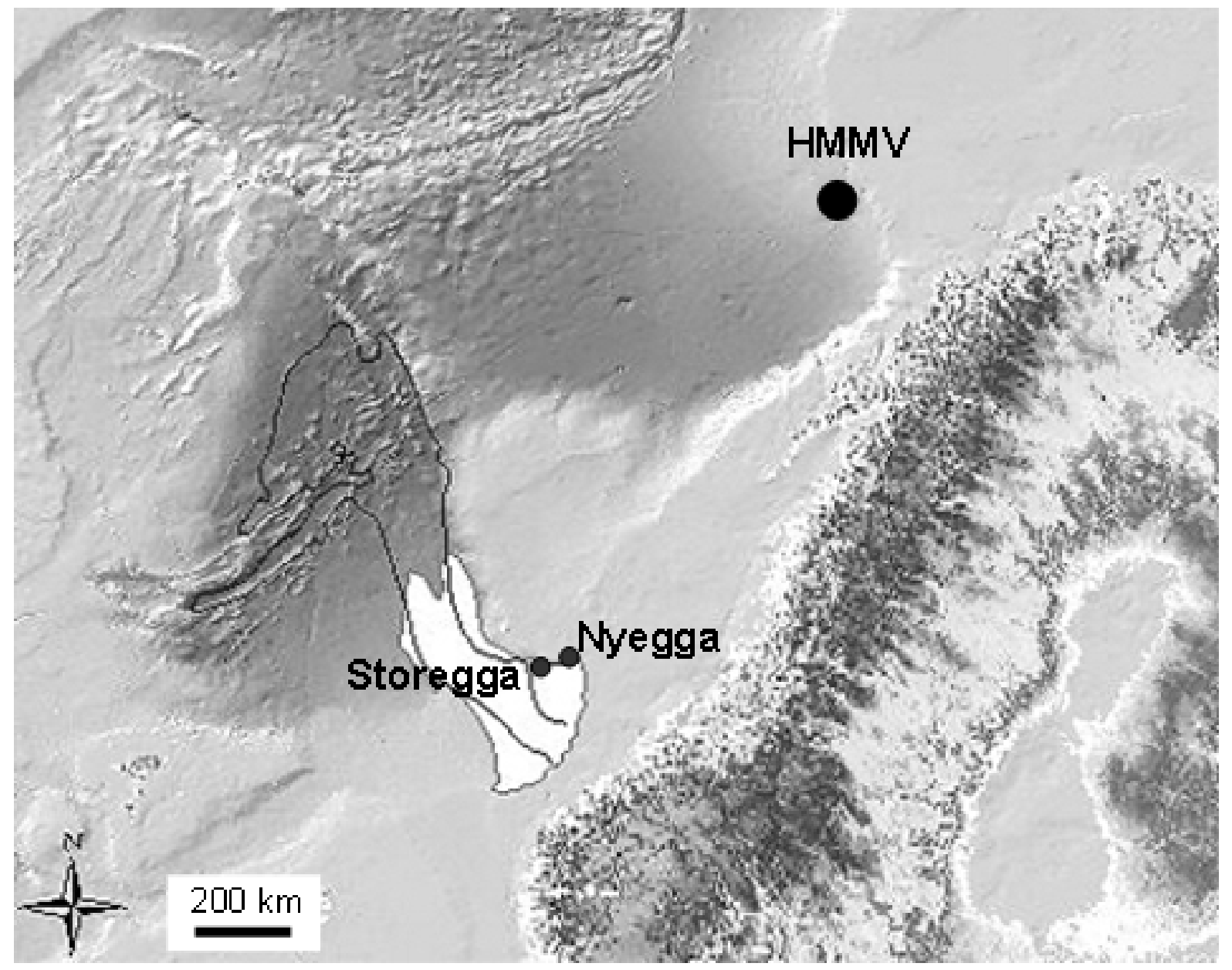

Figure 1: Map of the Norwegian margin with the three sampling locations. The northern is the Håkon Mosby Mud Volcano (HMMV), and the southern locations are the Storegga Slide and the Nyegga area. (HERMES Project, GIS Workpackage deliverables, Nordic Margins GIS webserver, http://gis-web.jacobs-university.de) 


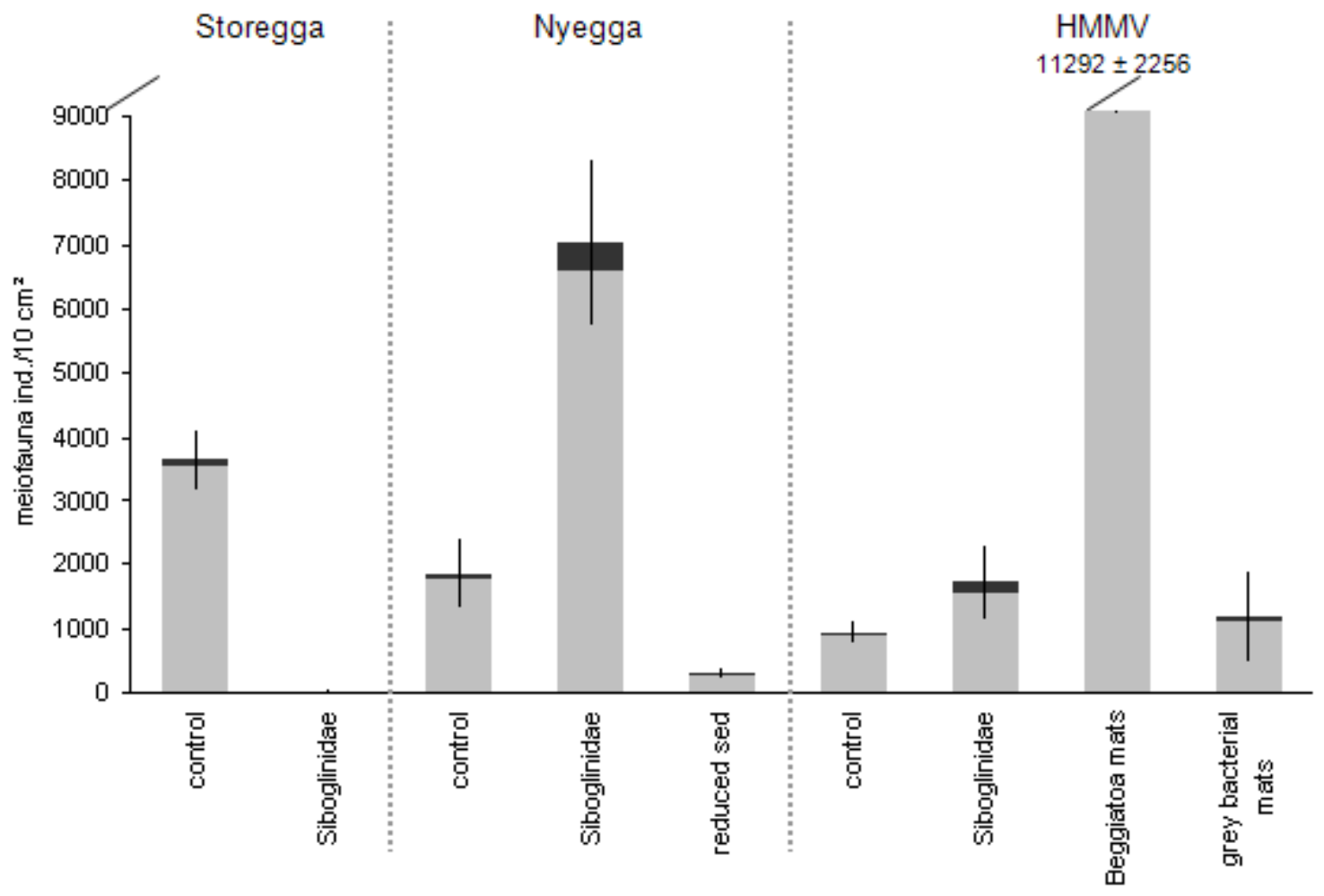

Nematoda $\square$ Other meiofaunal taxa

Figure 2: Mean total densities of meiofauna in the different habitats at Storegga Slide (740 $\mathrm{m})$, the Nyegga area $(730 \mathrm{~m})$ and the Håkon Mosby Mud Volcano $(1280 \mathrm{~m})$ (mean values \pm standard deviation). Total meiofaunal density in the Beggiatoa mats at HMMV reached $11292 \pm 2256$ ind. $10 \mathrm{~cm}^{-2}$.

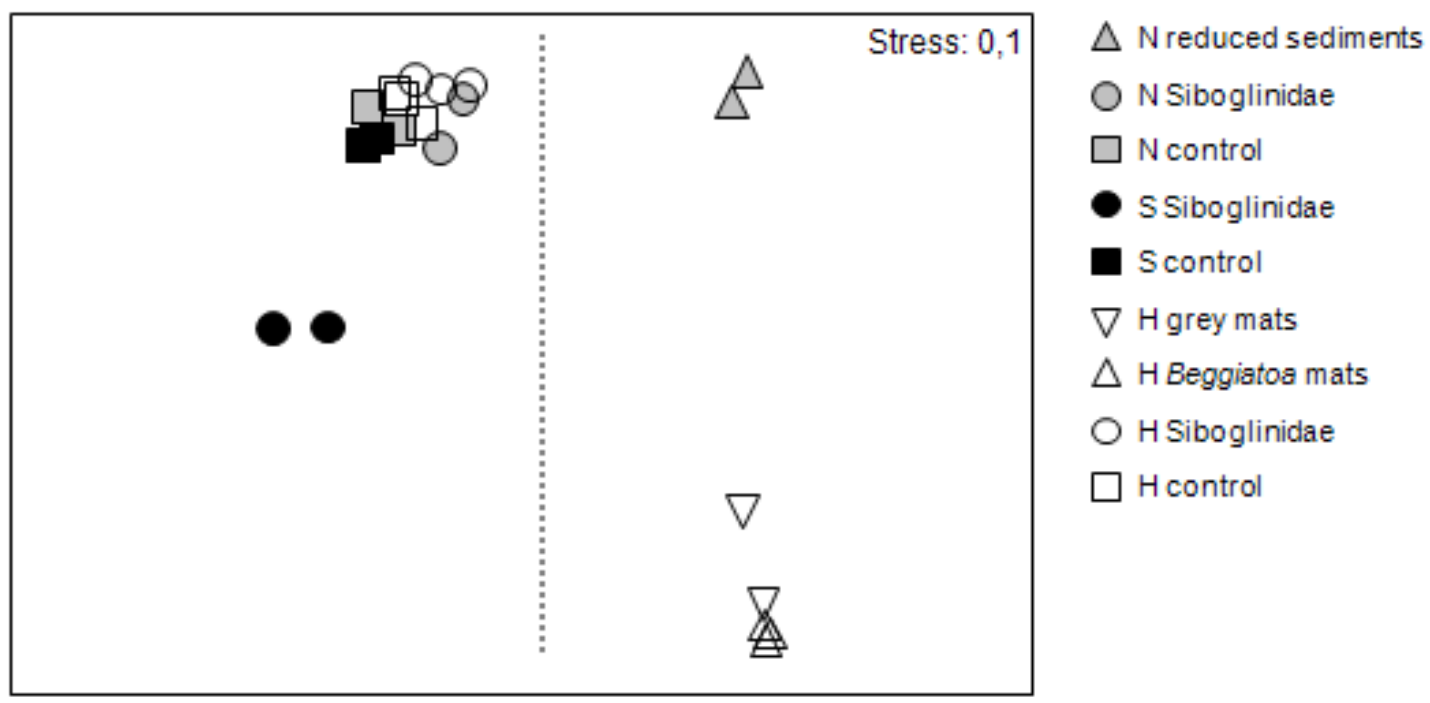

Figure 3: MDS ordination illustrating similarity of nematode communities in the different habitats at the Storegga/ Nyegga region and the Håkon Mosby Mud Volcano). All replicate samples were plotted. N: Nyegga; S: Storegga; H: HMMV. 


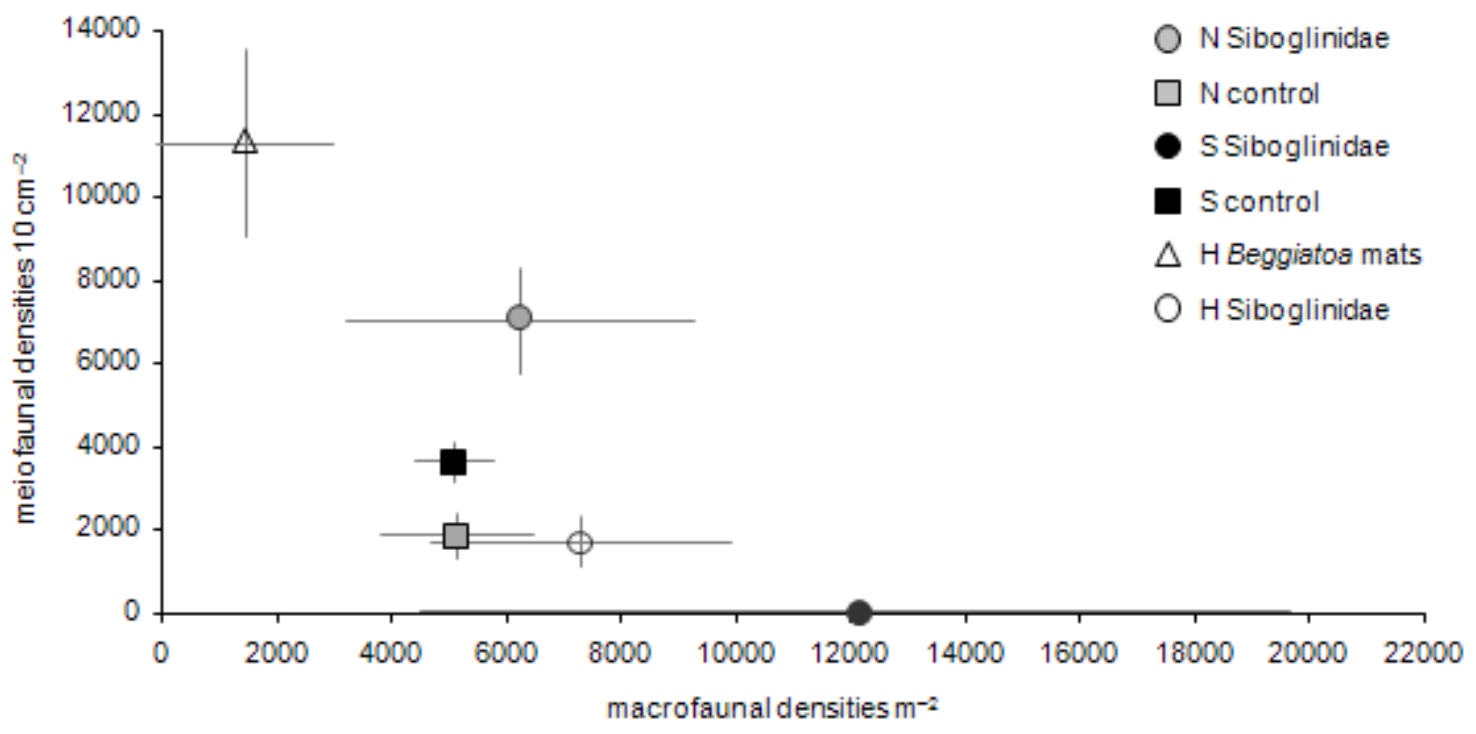

Figure 4: Meiofaunal densities in relation to macrofaunal densities in the control and Siboglinidae sites at Storegga and Nyegga and the Siboglinidae and Beggiatoa sites at HMMV (mean values \pm standard deviation). N: Nyegga; S: Storegga; H: HMMV. 


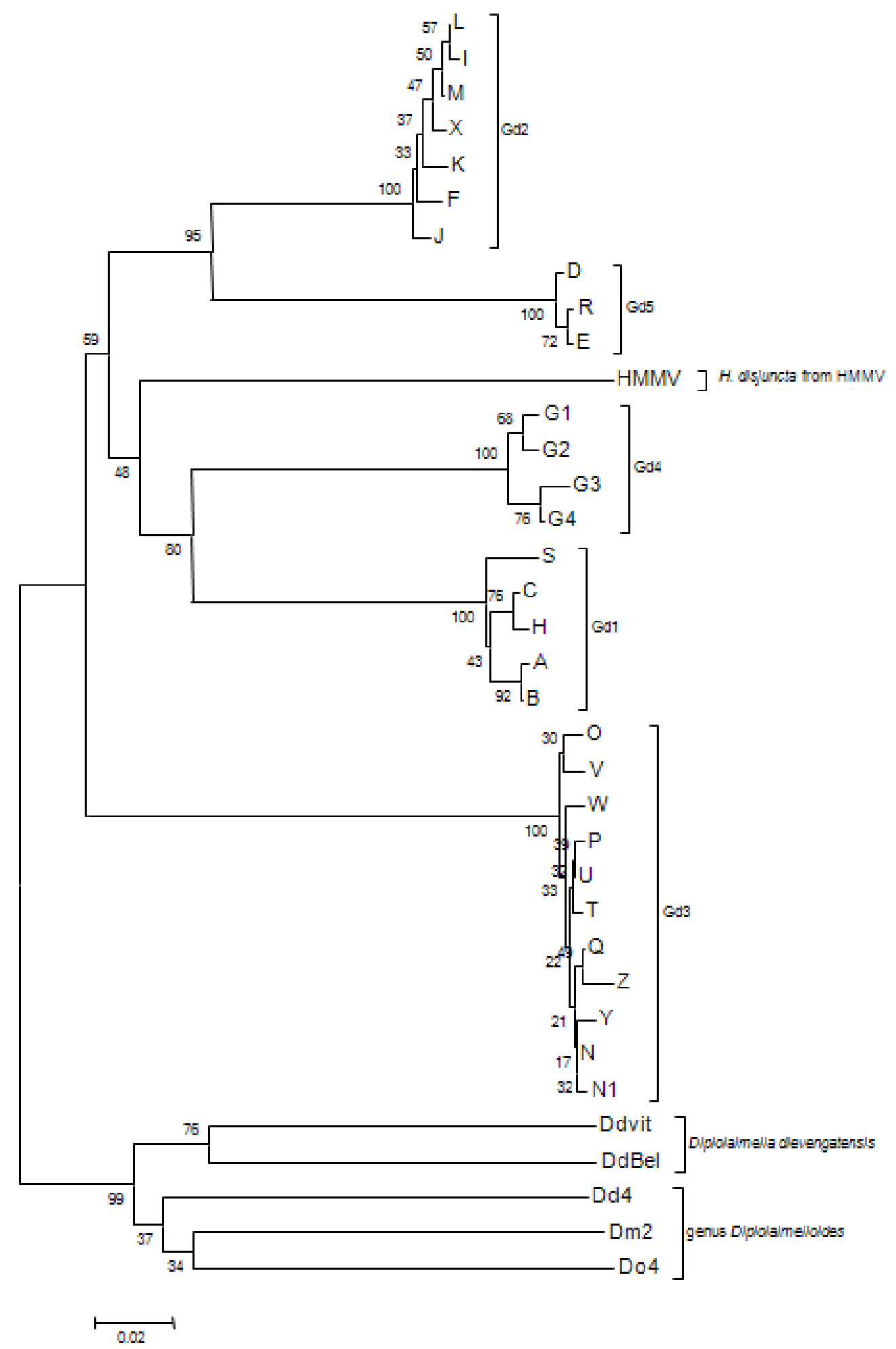

Figure 5: Phylogenetic position of HMMV among cryptic species of the Halomonhystera disjuncta species complex from Derycke et al. (2007). The closely related monhysterids Diplolaimelloides meyli, $D$. oschei, $D$. deleyi and Diplolaimella dievengatensis were used as outgroup. NJ tree of $\mathrm{COI}$ haplotypes with branch lengths calculated on the basis of Pdistances. Bootstrap values are based on 1000 replicates. Gd: Geomonhystera disjuncta (Derycke et al., 2007) 